University of Wyoming College of Law

Law Archive of Wyoming Scholarship

6-6-2015

\title{
Overcoming the Disability Deceptions
}

John M. Burman

University of Wyoming College of Law, jmburman@uwyo.edu

Follow this and additional works at: https://scholarship.law.uwyo.edu/other

\section{Recommended Citation}

Burman, John M., "Overcoming the Disability Deceptions" (2015). Other Publications and Activities. 2. https://scholarship.law.uwyo.edu/other/2

This Article is brought to you for free and open access by the UW College of Law Faculty Scholarship at Law Archive of Wyoming Scholarship. It has been accepted for inclusion in Other Publications and Activities by an authorized administrator of Law Archive of Wyoming Scholarship. 


\title{
Overcoming the Disability Deceptions.
}

\author{
John M. Burman ${ }^{1}$
}

“Three generations of imbeciles are enough.”2

The title to this article is based on a book called: "FDR [Franklin Delano Roosevelt]'s Splendid Deception,” the story about the extent of FDR's disability, and how he and the media combined to deceive the American electorate about FDR s disability. ${ }^{3}$ The quotation is from an opinion by the United States Supreme Court, written just five years before FDR was elected President, by Justice Oliver Wendall Holmes, Jr., that shows why the deception was necessary.

Although FDR lived a long time ago (from 1882 until 1945), and the enactment of the $\mathrm{ADA}^{4}$ (Americans with Disabilities Act) has eliminated many physical barriers, I have found that many psychological barriers remain, which are more difficult to overcome, because persons today continue to engage in massive deceptions about disabilities, deceptions which must be overcome before disabled Americans are truly equal. First, most persons believe (so this is a type of self-deception) that they, their family members, and their friends, will never become disabled (they may be right; instead of being disabled, one may die without becoming disabled). A second self-deception which often arises is that a person, such as myself, that is going to become disabled, talks himself or herself into believing that the disability will not occur. A third common deception is that a disabled person has a "condition," which has rendered him or her disabled, and is a "condition," not really a person. A fourth deception that may arise (normally among Americans ${ }^{5}$ ) is the belief that some disabled persons are not "worthy" of receiving medically necessary treatment, supplies or equipment. It is, therefore, morally acceptable to deny such treatment, supplies, equipment altogether. Perhaps as a result of these deceptions, another, major, deception arises. That is, disabled persons are second class persons, and they may be mistreated accordingly. These deceptions are alive and well, meaning, unfortunately, that FDR would have to participate in the same kind of deception today, though I doubt that the media would cooperate.

\footnotetext{
${ }^{1}$ John M. Burman is the Carl M. Williams Professor Emeritus of Law and Ethics at the University of, Wyoming College of Law. He "retired" from the college in 2013 because of his disability. He thanks Marilyn Paules Burman, Mary E. Burman, Tim Dean Crawford, and Michelle Jarman for reading and commenting on drafts of this article. Their comments were helpful.

${ }^{2}$ Buck v. Bell, 274 U.S. 200, 207, 47 S. Ct 584, 585.( 19 27), Oliver Wendell Holmes, Jr. (Upholding the Constitutionality of a Virginia statute that allowed the compulsory sterilization of unfit persons, including mentally disabled persons.

${ }^{3}$ Hugh Gregory Gallagher, FDR's Splendid Deception: The Moving Story of Roosevelt's Massive Disability-And the Intense Efforts Conceal It from the Public. (1999).

${ }^{4}$ Public Law 101-336. 108th Congress, 2nd session (July 26, 1990). The ADA is codified at 42 U.S.C. 12101

5 The word "Americans" is used because those countries which provide universal health care, by definition, have decided not to make a moral distinction among persons who need medical care.
} 
Several years ago, a disease from which I suffer, OPCA (Olivo ponto cerebellar atrophy), a degenerative neurological disease that affects my balance, vision, and speech, rendered me disabled. After years of being able to pretend ("deceive” myself) that I was "normal," I had to admit that I was disabled. Since then, I have become more and more disabled. I am now in a wheelchair, I'm legally blind, and I speak with difficulty. As a consequence, after about 50 years as an able-bodied person, I have experienced about a decade, and am now living, life as a disabled person. I have been surprised, both pleasantly and unpleasantly, at how others have treated me.

On one hand, most persons are very helpful and treat me well. On the other, some persons, including persons who should know better, such as healthcare professionals and others whose job it is to work with disabled persons, have treated me poorly.

In my experience, there is simply no comparison between the treatment accorded an ablebodied person and that accorded a disabled person. Persons who are not disabled receive substantially better treatment.

Often I think the behavior of those who treat disabled persons badly comes from a fundamental lack of understanding about what disabled persons want. Also, such persons often have a misguided belief that they know better.

A main reason that the above deceptions arise and flourish is that disabled persons are often regarded as non-persons, as the quotation which begins this article shows. They do not, therefore, need to be treated as persons who have rights. Once disabled persons are treated as persons, with rights, the deceptions will disappear.

This country was founded on individual rights ("all men are endowed by their Creator with certain unalienable Rights ... ." $)$. Perhaps because of that history, we tend to think of things in terms of "rights." In the last century, for example, we have seen the often successful struggles for women's rights, civil rights, and now, rights for same-sex persons. "Rights" to vote and to marry are among the "rights" that often take center stage. Another "right" lies beneath those rights. That is, the right of self-determination, which can also be properly described as "dignity" or "respect."

In 1948, the General Assembly of the United Nations adopted its Universal Declaration of Human Rights ${ }^{7}$ ("Declaration"). Although the United States was a "key supporter" of the Declaration, it, almost alone among "developed" countries, has, as discussed below, consistently refused to provide medical care, one of the specified rights, to all its residents, a decision that is

\footnotetext{
${ }^{6}$ The Declaration of Independence. Available online at http://www.ushistory.org/declaration/document/index.htm (last visited on May 30, 2015).

7 The Declaration is available online at http://www.un.org/en/documents/udhr/ (last visited on May 28, 2015).
} 
directly contrary to the Declaration, and a decision which has a disproportionately negative impact on disabled persons). The Declaration has its critics, but it is generally recognized throughout the world as perhaps the most important statement of rights ever made. ${ }^{8}$ While the Declaration contains 30 "rights," some of the most important language is found in the preamble. "Whereas recognition of the inherent dignity and of the equal and inalienable rights of all members of the human family is the foundation of freedom, justice and peace in the world."9 The references to "the inherent dignity" and the "equal and inalienable rights of all," are, in my view, the basis (the "foundation" in the words of the Declaration) for everything that follows, and the key to what all of us need and want.

"Dignity" means to act in a way that is "indicative of self-respect." 10 The word "selfrespect" is the critical one. "Self-respect” has two parts. The first, "self," has an obvious meaning. The second, "respect," deserves more attention, whic will h it receives below.

"Equal and inalienable rights of all” makes the valuable and often over looked point that no group needs special rights. Rather, we (here, I use "we" to refer to the group of which I am a member-disabled persons) just want the same "rights" as persons who are not disabled.

The main right we want is to be respected. "Respect" has many definitions. The one I like is: "esteem for or a sense of the worth or excellence of a person." 11 That phrase sums up the concept to me. One must value a person to have "a sense of that person's excellence.” ${ }^{12}$ To value another is what we all want. Here, therefore, "respect" means that since you value a person, you are willing to admit that you do not know what is best for that person and you are willing to accept the proposition that everyone is "worthy” of receiving medically necessary health care, regardless of your education, experience, or position in life. In fact, while I, as a disabled person, am interested in what you have to say as it relates to my condition or the services you provide, your opinions about what is "best for me," are irrelevant, so irrelevant that I don't want to even hear them. Instead, I want you to support whatever decision I make. If you do not agree with my decision, please be quiet.

I am also more than a little annoyed that too many non-disabled persons appear to think that the time of disabled persons is of little or no value. It is, according to this view, fine to adopt a program that requires disabled persons to wait, because their time is allegedly very secondary to, for example, administrative efficiency. Making a disabled person wait is thought to be of no real concern because, after all, it is only a disabled person, and how much can his or her time be

CRITICAL RACE THEORY AS INTERNATIONAL HUMAN RIGHTS LAW

93 Am. Soc'y Int'l L. Proc. 228 (1999) ("We can agree on some basics- the principles forth in the Universal

Declaration of Human Rights ....”)"

9 Supra note 7 at Preamble.

${ }^{10}$ Dictionary.com, http://dictionary.reference.com/browse/ (last visited on November 13, 2014).

${ }^{11} \mathrm{Id}$.

${ }^{12} I d$. 
worth? A lot, is the correct answer. After all, the condition which led to the disability may well mean that a disabled person has substantially less time to live than a person who is not disabled. Not valuing the time of disabled persons is one more way of saying "we don't respect you." Often, decisions to make disabled person wait are made by non-disabled persons with little or no input from disabled persons. The theory, I guess, is that non-disabled persons "know" what is better.

Another common reaction to a decision of a disabled person is for some non-disabled persons to suggest that the disabled person has not really thought about the matter. On the contrary, it is almost always the case that the disabled person has thought about the issue far more than the non-disabled person. The unfortunate reality is that disabled persons live with their disabilities 24 hours a day, 365 days a year. A disabled person does not get vacations. One is just as disabled on Christmas morning as on every other morning of the year. Part of being disabled, is that one has lots of time to think. As a result, the decisions of disabled persons are usually carefully thought through. The least others can do is respect the decisions of disabled persons ("respect” means “accept," regardless of whether you think the decision is "correct”).

Every disabled person has experienced the phenomenon of being "invisible," while only his or her disability seems to be "visible," at least to some others. This deception occurs when another person "sees" only the condition that has caused the person to have become disabled, and not the person who happens to be disabled. Ignoring the person, and focusing, instead, on the person's condition, allows the "deceived" person to reject the disabled person as a person, and deal only with the condition. Disregarding a disabled person and concentrating on that person's condition, may be easier for the non-disabled person, but it is very disrespectful to the disabled person, perhaps as disrespectful as anything the able-bodied person could do.

The "right" to proper health care, critical to disabled persons, is both a mandate of the Declaration, ${ }^{13}$ and a common feature of health care systems in "developed" countries, except in the United States.

While Americans tend to think they have excellent health care, not everyone agrees. While those Americans who have access to the system do relatively well, the millions of Americans who have no such access do not. ${ }^{14}$ Accordingly, collectively Americans do not live very well, at least according to some authorities. For example, in 2000 the World Health Organization ("WHO"), a part of the UN, ${ }^{15}$ evaluated the health care systems in 191 countries. In what has been described as the "most ambitious" 16 attempt ever made to rate different health care systems, the United States came in 37th, between Costa Rica and Slovenia, and behind Japan, the United Kingdom, Columbia, and Germany, among many others (France received the

\footnotetext{
${ }^{13}$ Supra, note 7 at art. 26.

${ }^{14}$ T. R. Reid, The HeAling Of AmericA, 256 (2010).

${ }^{15} \mathrm{Id}$. at 260

${ }^{16}$ Id.
} 
top ranking). ${ }^{17}$ The United States scored particularly poorly on "goodness" and "fairness." The former term, "goodness," refers to "how well a country did at keeping its people healthy ...." 18 The latter, "fairness," focuses on two factors:

1. How equally the system treated the rich and the poor.

2. How a national health care system was financed. For the WHO, a progressive financing system, in which rich people paid more than the poor to finance health care for all, was an essential element of 'fairness. ${ }^{\text {'19 }}$

One of the criticisms of the WHO report was that it did not give any consideration to patient satisfaction. Accordingly, the following year, the Harvard School of Public Health measured the satisfaction of patients in 17 developed countries (Canada, the United States, and 15 countries in Europe). ${ }^{20}$ The United States scored 14th out of those 17, with only $40 \%$ of Americans expressing satisfaction with their health care. By contrast, Denmark led the pack, with $91 \%$ of Danes saying they were satisfied with their health care. ${ }^{21}$

It is, of course, impossible to fairly evaluate the health care systems of different countries. Some will do well on one evaluation, and poorly on another. Given all the various ranking systems, only general trends emerge. Perhaps all that can be safely said is: "there is a coterie of developed countries that is providing quality health care, distributing it fairly and equitably--and doing all that for much less money than the United States is spending."22

The changes from the Affordable Healthcare Act (“Obamacare”) will not make much difference. Perhaps most importantly, Obamacare will not result in universal care in the United States, a goal to which this country committed itself in 1948 (with its support of the Declaration), and a goal that has been achieved, in virtually every developed country other than this one. ${ }^{23}$ Even after Obamacare is fully implemented, more than 20 million Americans will be without adequate health care coverage, resulting in the preventable deaths of thousands of Americans per year. Many disabled persons will be among them.

Not surprisingly, disabled persons need more medical treatment, supplies, and equipment than non-disabled persons. ${ }^{24}$ The denial of those things to some persons, therefore, has a disproportionate effect on disabled persons.

\footnotetext{
${ }^{17}$ The WHO report is available on-line at http://patientfactor.com/canadian (last visited on January 3, 2015).

${ }^{18}$ T. R. Reid, THE HEALING OF AMERICA, (2010) 262

${ }^{19}$ Id. at260.

${ }^{20} \mathrm{Id}$. at 264.

${ }^{21}$ Id. at 264-5.

${ }^{22} I d$. at 266.

${ }^{23} \mathrm{Id}$. at seriatim.

${ }^{24}$ National Center on Birth Defects and Development Disabilities, Centers for Disease Control and Prevention (2014). Disabilities and Health Data - Health Overview. Available on-line at: http:dnds.cdc.gov/dualareprofiles/prolife? (Last visited on March 2, 20`5).
} 
FDR, and I, were lucky. FDR was independently wealthy. He could, and did, spend a considerable amount of his fortune on health care $^{25}$ (if he had not been wealthy, FDR would not have been able to engage in his "splendid deception”). While I am not similarly wealthy, I have the next best thing-good health insurance. That insurance has paid for tens of thousands of dollars for health care for me, as well as tens of thousands of dollars for health care for my wife, who is also disabled (I know disabled persons who have not been as lucky. They have been denied medically necessary care.). As is almost always the case, my disabilities and those of my wife are the result of factors completely beyond our control. Whether I or my wife, are, therefore, "worthy" of having received such medical care, supplies, and equipment is impossible to guess. While I would like to think that I and my wife are "good" persons, I have no idea what makes a disabled person "worthy" of receiving medically necessary health care in this country, other than qualifying for Medicare. Supporting the Declaration's mandate to provide "medical care” for all, and then refusing, since 1948, to grant that right to Americans (when almost all other "developed" countries provide such care), seems to be the height of hypocrisy. Further, making a moral distinction between "worthy" and "unworthy" persons when the need for health care does not depend on "fault," makes no sense.

One of the strange features of the health care "system" in this country, is that every person age 65 or older, receives Medicare, government funded health insurance. ${ }^{26}$ Accordingly, persons over age 65, in this country, will receive medically necessary treatment, supplies, or equipment. Younger persons, may, however, be denied such treatment, supplies, or equipment.

I have yet to hear an attempt to explain the moral basis for treating the elderly (those 65 and older) better than those who are younger, especially children. Yet many persons (usually Americans) apparently find such a distinction morally acceptable. Permitting this deception allows one to accept the proposition that it is morally appropriate to deny medically necessary medical treatment, supplies, or equipment to some disabled persons.

To me, however, the idea that some (younger) persons are not worthy of medically necessary treatment, supplies, or equipment, and that others, including all persons 65 or older are, is a massive deception (which has become a political issue) that will be very difficult to overcome. Furthermore, denying medically necessary health care exhibits an astonishing lack of respect for disabled persons.

I know that providing health care coverage to all would cost money (though all countries that provide universal health care do so for much less, per capita, than is currently spent in the United States. ${ }^{27}$ ), probably in the form of higher taxes. As one who would likely have to pay

\footnotetext{
${ }^{25}$ See supra, note 3, seriatim, for a discussion of the time and money FDR spent looking for a "cure," before he began his deception.

${ }^{26}$ Merton C. Bernstein, The Viability of Social Security and Medicare in an Aging Society, 28 Soc. Sec. Rep. Serv. 694, 707 (1990).
}

27 T. R. Reid, THE HEALING OF AMERICA, (2010) 252 
such taxes, let me say I would be happy to. I would gladly pay because I believe we have the same moral obligation as the residents of other "developed" countries, and I believe in the right this country supported in the Declaration; the right to appropriate medical care (the support of the United States was so important that from the moment that the United Nations adopted the Declaration, "there was at least a presumption that the United States should promote the Declaration's provisions because it had been a key supporter of the Declaration during its negotiation and adoption.”) ${ }^{28}$ The simple truth is that sickness, or whatever may cause a disability, strikes without regard to whether one is "good" or "bad." To think that one has a choice, or that only "bad" persons become sick or disabled, is an enormous deception. It is the kind of deception that will leave one speechless when one must pay, as we must (through our insurance company), over $\$ 15,000.00$ per month in medical expenses.

A far too common attitude, used to justify treating disabled persons poorly, is "we are doing what the law requires, and that should be enough." That, quite frankly, is nonsense. The question should not be "what does the law require," but "what is the right thing to do?"

Perhaps former vice-president Humphrey put it best. "The moral test of government is how that government treats those in the dawn of life, the children, those in the twilight of life, the elderly, and those in the shadows of life, the sick, needy, and the handicapped." 29 The second word, "moral," is the key. The question is not, and should not be, "are we doing what we must?" Rather, the definition of the word "moral," which is "pertaining to, or concerned with the principles or rules of right conduct or the distinction betwee n right and wrong," 30 makes the question clear. However one wants to interpret "moral," it certainly includes the fundamental notion of "right." The question, therefore, is, and should be, "what is right”? Furthermore, the word "governments," should, I think, be replaced with "person or entity." With this as a standard, many persons and entities fail, miserably, because they do not do what is right. That, in fact, is not even their objective.

The reason for that failure is, too often, not respecting disabled persons.

That is what respect is all about. Just as I don't know what is best for you, and I would never presume to decide that, the fact that I am disabled does not mean that I am not a person. I am, and please don't forget that.

\footnotetext{
28 Tai-Heng Cheng, The Universal Declaration of Human Rights at Sixty: Is It Still Right for the United States?, 41 CORNELL INT'L L.J. 251, 254 (2006

${ }^{29} \mathrm{http}: / /$ www.brainyquote.com/qyotes/quotes/ (last visited on October .26, 2014).

${ }_{30}$ Dictionary.com, http://dictionary.reference.com/browse/ (last visited on November 13, 2014).
} 
I want to conclude with the observation that while I wish I had not been treated as a second class person because I am disabled, that wish has not been granted. I have, more often than I wish. I have been virtually ignored, because, I think, it's easier to ignore a disabled person, and deal with a non-disabled persons, or to ignore disabled persons entirely. While it may be easier to ignore a disabled person, nothing, as discussed above, is more offensive to a disabled person than to be ignored.

I began this article with the assertion that the most important right is the right of selfdetermination. Much of the article is about "dignity" and "respect." To me, the words "selfdetermination," "dignity” and "respect” are synonyms. It is, in other words, impossible to treat another with dignity or to respect this person, and not accord that person the right of selfdetermination. So, it all comes down to one concept: respect and dignity, rights that cannot be enforced, rather "rights" that have to be lived. ${ }^{31}$ And rights that belong to everyone, including disabled persons.

\footnotetext{
${ }^{31}$ The difference between "rights" that are written, and rights that are lived, is easily shown by considering the United States' support of the guarantee of providing "medical care" to all in the Declaration. Yet after more than 65 years, Americans, alone among residents of developed countries, have no such right. It is clear, therefore, that reality means much more than theory.
} 